\title{
TEMPORARY STREET TRANSFORMATION AS AN INTERVENTION FOR MORE PEOPLE FRIENDLY ENVIRONMENTS IN CITIES, A CONTRIBUTION WITHIN THE FRAME OF TACTICAL URBANISM
}

\author{
DOI: https://doi.org/10.18509/AGB217-40137s \\ UDC: 711.73-048.25:712.254-022.326 \\ Magdalena Senger, Michael Giesch, Wolfgang Fischer \\ Department of Geography and Regional Science, University of Graz, Austria \\ corresponding author:
}

submitted: 04.01.2021

accepted: 03.03.2021

published: 20.07.2021

\begin{abstract}
The paper in hand reflects on a research project named "Pop-up Piazza". It explores transformative tools for the temporary transformation of public space on streets. The principle is to test temporary measures from smaller actions like parklets to bigger actions such as closing streets for traffic before detailed planning or cost-intensive structural changes are made.

Public street space is largely dominated by motor vehicle use. Our pop-up transformations test other traffic conditions and enable a perception of the car-free space and its potential to make public space more people-friendly. Small, simple and inexpensive interventions should make the application easier for many cities. To implement this, we have developed cargo bike-based prototypes (so called Street Formators) within the project and are testing them in the urban spaces of Vienna and Graz. In addition to the development of prototypes and pilot testing in different frameworks, another focus lies on the impact evaluation of the implementations. Recommendations for policy makers, administrators, planners and developers will be derived from the results of the evaluation.

The case studies Graz and Vienna show that the framework conditions strongly contribute to the success of the measures. The temporary transformation of public street space creates more space for social interaction, fulfills an important function for neighborhoods and thus contributes to the quality of life in cities.
\end{abstract}

Keywords: tactical urbanism, streets for everyone, sustainable urban development, livable city, public space

\section{INTRODUCTION}

In urban areas - influenced not least by population growth and urbanization processes - various challenges are becoming increasingly apparent. Urban planners and developers are faced with problems such as degradation of air quality, noise pollution, rising temperatures and much more. Solutions to these must ensure that the current development results in well-functioning environmentally friendly and sustainable cities. For this, a combination of factors is needed. One of them is the proper administrative structures that influence outcomes in many areas that contribute to a functioning city. These include in particular transportation planning and land use planning. Specifically, ordinances must strike a balance between protecting existing neighborhoods, green space, and new development. In the context of transport, increasing the quality of public transport is particularly important, as are low incentives for car use to address impacts such as air pollution or congestion [1].This impressive call for a mobility turnaround is strongly linked to a reprioritization of urban street space in favour of sustainable modes of transport. Since the rise of the car, people have been increasingly marginalized - in favour of motorized transport. But since the street is more than a space to get around - street space fulfils key functions such as commerce, play, social interaction, leisure, etc. - this development has been increasingly challenged in recent times. Therefore, there are attempts to transform the streets in urban areas away from the use by motorized individual traffic towards active mobility and public spaces. The vision behind this is to create "streets for people" to use as recreational spaces, for playing and as places for social interaction [2] [3] [4].

Austria has comparatively little experience in this area. Exceptions are pedestrian zones such as Mariahilferstraße in Vienna [5] and Sonnenfelsplatz in Graz ("shared space") [6] or in front of a few schools and residential streets where traffic-calming measures are in place. In the 
majority of cases, however, the public traffic space is dominated by motorized individual traffic. To a large extent, this space is "blocked" by parked cars.
A look at the spatial distribution of stationary traffic in Graz makes this more than clear:

Table 1. Spatial distribution of stationary traffic in Graz(source: Austrian Mobility Research 2016, based on data from the City of Graz)

\begin{tabular}{|l|c|}
\hline & Land requirement (in \%) \\
\hline Bicycle parking facilities & 2 \\
\hline Pedestrian areas & 3 \\
\hline Areas for public transport & 3 \\
\hline Car parking space & 92 \\
\hline
\end{tabular}

One way to address this challenge is to view streetscapes as experimental spaces where solutions can be tested - the paradigm is "learning by doing". The experience should contribute to a better understanding of the opportunities [7].

This paper will explore the possibilities of such temporary transformations and the framework

\section{THEORETICAL FRAMEWORK}

Tactical urbanism consists of low budget and smallscale interventions to generate a more livable environment in cities. Synonyms are "pop-up" and "guerilla" urbanism [8]. The goal is to make a big impact at low risk. The interventions should be shown to a broad audience to give them an idea of possible changes. People should get the experience of what could make their city life more colorful, safer and easier. Changes could range from coloring bicycle lanes up to transforming parking space into chillout areas to flee the daily stress occurring in a pulsating city. Biggest impact of tactical urbanism is generated, when residents or communities start to engage in city planning [9] [10] [11].

Tactical Urbanism is not a new phenomenon. For a long time, cities have had to face different challenges. Adaptations to new economic systems were demanded as Lefebvre addresses in his book "Writings on cities". Planning is done by intellectuals and every possible aspect is included [12] [13].

The focus of urban planners is primarily on securing settlement developments, use of land for buildings and the design of traffic areas [14] [15]. However, no one asks how people feel along busy roads. Nobody asks what elderly people would like to have on their daily walk: e.g. a seating accommodation to rest when walking longer distances. Who thinks of the needs of children living on highly frequented roads? Today the planning of the city is mainly based on factors of economic importance. conditions that contribute to success. After a review of the theoretical framework of tactical urbanism and its current state of research, we will focus on the research project Pop-up Piazza. After outlining the contents and goals, we present our interim results of the surveys in the case studies Vienna and Graz (both cities in Austria).

Tactical urbanism is a means for city dwellers to express their needs. This informal approach, which might fall under civil disobedience, all the same achieves its goals. Often, short-term interventions are recognized and adopted by official bodies at a later stage. For example, the project "walk [your city]" showed this. The American city Raleigh first banned the project as illegal. Due to high media attention and high support of the citizens, officials shortly afterwards reinstated the intervention and declared the changes as a pilot project [16].

Tactical urbanism can be found in many cities. In Vienna, a temporary improvement is achieved within the framework of the "Coole Straßen" (in English: "cool streets" - further on this term is used). On a heat map, places are selected which need cooling down during the summer months and thus interventions such as closing automotive traffic, water sprinklers, mobile plants in large pots and installing meeting places [17]. The "Grätzloase" (in English: "neighbourhood oases") can be mentioned here as another action program. The initiative shows how small spaces in the neighbourhood can be used and bring life back to the streets. To achieve this, mostly parklets are employed - a use of car parking spaces as lounges. In addition to this method, which has already been used in Vienna, but mostly for longer periods - e.g. the parklets are set up for a season or longer - we want to test simple and quick pop-up transformations in the course of the project with the help of a new tool [18]. 
THE "POP-UP PIAZZA” PROJECT

Changes of built environment in cities are generally accompanied by long lasting decision making and planning processes. This circumstance makes it more difficult to implement modern urban development concepts that are intended to bring about a transformation in mobility patterns and to make public spaces more people- and childfriendly. The statement of intent might be written down on paper - but very often there is a lack of budget, time and consensus around the kind of measures that should be implemented. Often these obstacles are irremovable.

Temporarily freeing traffic areas from cars and transforming them into public spaces, offers a "lowcost", "low-time" and "high gain" opportunity to reduce the obstacles associated with the transformation of urban structures towards new traffic concepts and paradigms. The principle is to temporarily test a measure before the cost-intensive detailed planning and implementation of construction measures. A wide variety of temporary transformations is to be developed as an efficient, potentially widely used planning and implementation tool for sustainable, permanent solutions.Pop-up Piazza aims to make the temporary transformation of streets and squares

\section{EXPERIENCES WITH THE}

\section{TRANSFORMATION OF STREET}

\section{SPACES IN DIFFERENT CONTEXTS}

A central point of the project are the interventions, i.e. the "testing out" of the StreetFormators in different settings and the evaluation of the impact. The goal is to conduct 20 and 10 interventions in the cities of Vienna and Graz, respectively. Due to the changed situation caused by Covid, there were delays in the implementation and adjustments had to be made. Thus, instead of the prototypes, the so- much easier and faster to implement and to make it easy for Austrian cities to apply. The goal is to create an efficient tool for a widely applied, multifaceted transformation of public spaces that will significantly accelerate the mobility turnaround. The main results of Pop-up Piazza will be [19]:

-Development and testing of cargo bike-based research prototypes, which - as mobile "StreetFormators" - will enable fast pop-up transformations.

-(Further) development and testing of a digital citizens' tool, which is suitable for the broad employment on different topics all over Austria.

-The respective "testing" is about the validation of the functionalities - how the respective solution is proven or not proven in the real laboratory environment.

-State of the art analysis and analysis of the legal and organizational framework conditions

-Evaluation and recommendations for policy, administration, planners and developers

-Efficient dissemination of research results, opensource access for prototypes and the citizens' tool. called StreetFormators, which had not all been built yet, the existing "Raumwandler" (in English: "space-transformers") from the previous project Metamorphosis were used (in Graz). One readybuilt StreetFormator - a cargo bike equipped with games, fun and sports equipment - was already in use in Vienna.
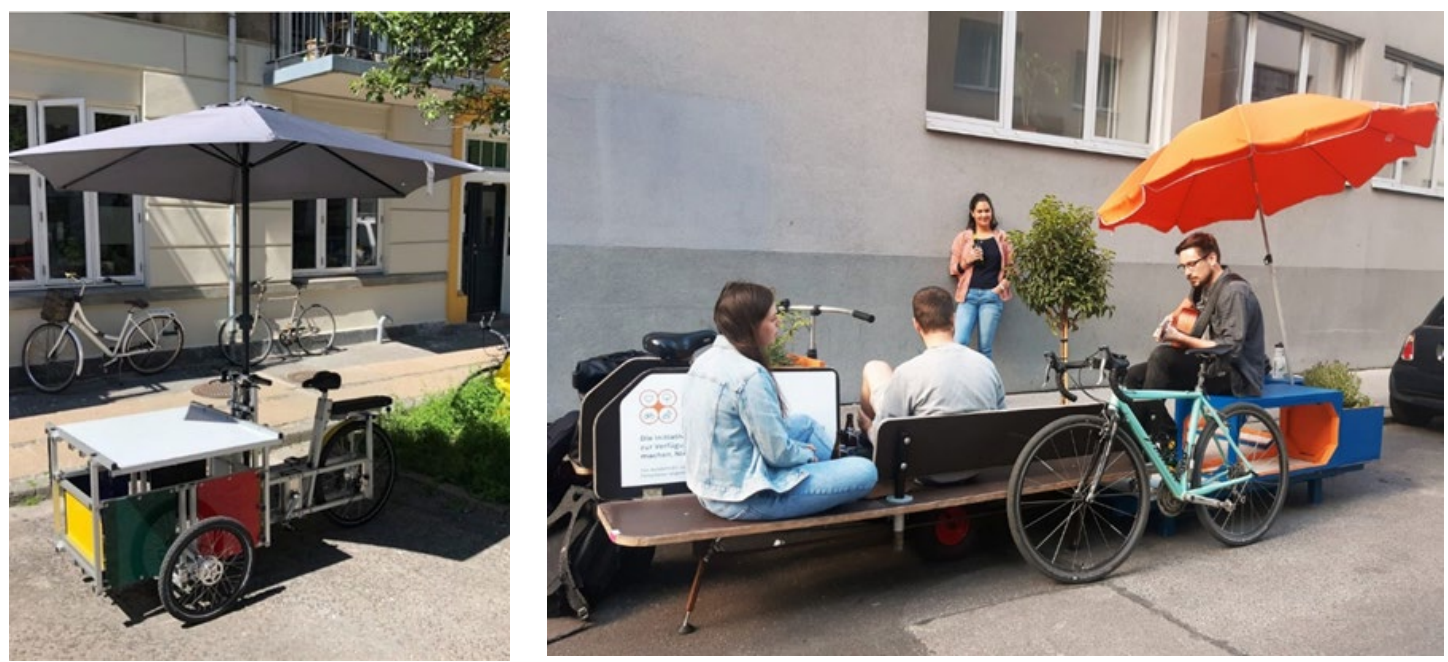

Figure 1: The new StreetFormator called "playing-bike" and the existing space-transformers (Sources: xyz cargo 2020; metamorphosis 2020) 


\section{Magdalena Senger et al.. \\ Temporary street transformation as an...}

In addition to the different transformation tools that were used, they were also applied in different contexts. While the main focus in Graz was a host system, in Vienna the use was carried out in the context of events (see table 2) [20].

Table 2: Difference in the way of interventions in Graz and Vienna

\begin{tabular}{|l|l|l|}
\hline & \multicolumn{1}{|c|}{ Graz } & \multicolumn{1}{c|}{ Vienna } \\
\hline Type of prototypes used & $\begin{array}{l}\text { Space-transformers (which } \\
\text { were developed for the } \\
\text { Metamorphosis project) as a } \\
\text { replacement for StreetFormators } \\
\begin{array}{l}\text { "garden mobile" and } \\
\text { "classic" space-transformers } \\
\text { (see figure 1) }\end{array}\end{array}$ & $\begin{array}{l}\text { StreetFormator } \\
\text { (playing bike) (see figure 1) }\end{array}$ \\
\hline $\begin{array}{l}\text { Context in which the } \\
\text { prototypes were used }\end{array}$ & $\begin{array}{l}\text { Space-transformers: host } \\
\text { system and unsupervised } \\
\text { release; } \\
\text { "garden mobile": in cooperation } \\
\text { with the Social Welfare Office } \\
\text { of the City of Graz and a host } \\
\text { system }\end{array}$ & Event "Cool Streets" \\
\hline Participation principle & $\begin{array}{l}\text { Modified bottom-up } \\
\text { (Cooperation with local } \\
\text { associations, institutions and } \\
\text { companies) }\end{array}$ & $\begin{array}{l}\text { Top-down } \\
\text { (Cool streets: official closure of } \\
\text { the streets) }\end{array}$ \\
\hline
\end{tabular}

The Graz deployments were conducted in a "modified bottom-up" framework. Specifically, this means that the selection of the sites themselves was not a top-down measure on the part of authorities or administrative units. Nor have citizens themselves had any direct influence on the location of the deployed space-transformers yet.
Instead, cooperative partnerships were formed in which the location was jointly fixed. In addition to the project partners, non-profit organizations, local companies and associations were represented in such partnerships [20]. In figure 2 some of these collaborations are shown
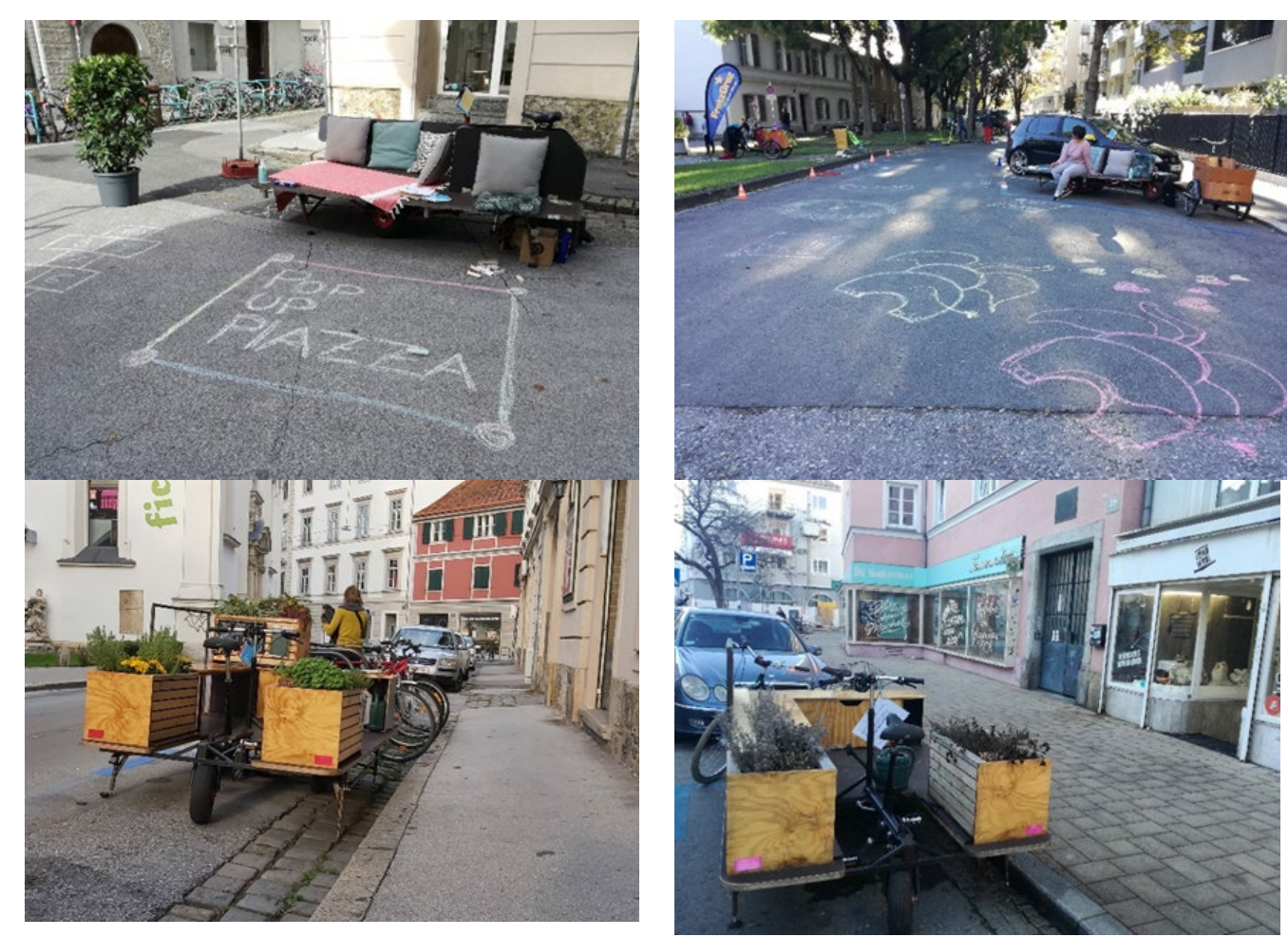

Figure 2: Types of collaborations (from top left to bottom right): joint play of temporary play streets and residential streets with the "space-transformer"; host system - here: "Garden Mobile" hosted by a neighborhood center and a local store (own images, 2020/21) 
Based on the experience of the pilot tests in residential streets in Graz, it can be concluded that the Pop-up Piazza project can make an important contribution towards raising awareness. On the one hand, many passers-by asked about it, were interested in the idea and gave positive feedback about creating a lounge "on the doorstep". However, there have also been many violations of the prohibition of passing through the street, which is set out in the road traffic regulations. However, these could be made aware of their misconduct through the campaign and above all through the targeted playing on the street - which is expressly permitted in residential streets. Here, with a little support, the street space was reclaimed by children.
In addition, the residents were able to enjoy the benefits of the traffic-calmed area and were made aware of it.

In this case, it was particularly evident from the traffic count how important it is to conduct awareness work (see table 3 ). It should be noted that drivers of cars or motorized two-wheelers are not fully aware of the special regulations for residential streets or ignore them. In both survey periods, there were numerous violations of the road traffic regulations. One can even speak of a vicious circle here, since this traffic in turn creates an unsafe environment and as a result children of residents are not allowed to play on the street at all [20].

Table 3: Traffic count results of the pre-survey and the survey during

the intervention in the residential street (Muchargasse) in Graz.

\begin{tabular}{|c|c|c|}
\hline Survey & $\begin{array}{c}\text { 25 July 2020 (4-5pm) } \\
\text { (before intervention) }\end{array}$ & $\begin{array}{c}\text { 22 September 2020 (4-5pm) } \\
\text { (during intervention) }\end{array}$ \\
\hline $\begin{array}{c}\text { Trassenger cars (of which passed } \\
\text { through) }\end{array}$ & $15(7)$ & $37(23)$ \\
\hline Pedestrians & 72 & 123 \\
\hline Cyclists & 36 & 150 \\
\hline Motorcycles & 0 & $6(5)$ \\
\hline Skateboarders & 2 & 3 \\
\hline
\end{tabular}

In addition to pilot testing in residential/playground streets, the host system has also proven to be viable (meaning the use of space provided by third party hosts such as stores). Hosts provide some sort of care/surveillance for the space-transformers, which limits vandalism and littering. Experience has shown that space-transformers that have been "released" have been violently moved or even intentionally damaged a few times. So if someone is monitoring it on the side, there is more security. It also takes away a barrier. This is because many passersby do not perceive the space-transformer as a public space and do not know that they are allowed to use it without further ado. Good experiences have therefore been made especially when the cargo bike transforms car parking spaces into recreational areas in cooperation with district centers or neighborhood offices. These can actively use the space as part of their activities.

One inhibiting factor, especially in Graz, is the administrative framework. Although it is legally permitted to park cargo bikes in a parking lot if they meet certain points, the general approach of the authorities is not to allow this. The restrictive nature of the road authorities makes such implementations in Graz considerably more difficult.

The implementations in Vienna took place mainly within the framework of organized events. During the summer months, 18 street(-sections) in Vienna were temporarily transformed into so-called "Coole
Straßen" ("Cool Streets"). The project is a heat adaptation measure. It is intended to allow cooling in the middle of the city as well as to create free space for the residents. Based on the Vienna heat map, locations were selected that are particularly affected by the heat. The age of the population was also taken into account here, as older people and children have a lower tolerance for heat. During implementation, there was a ban on driving, stopping and parking cars, and instead there were water sprinklers, plants and seating areas. Children were able to use the freed-up space for playing, and adults were also given a place to stay. Bicycling was still possible [17]. The StreetFormator, in this case the playing bike, was also used for the "Cool Street". It brought various toys and sports equipment to the "place of action" and thus took over an important supplementary function for temporary traffic relief. Figure 3 shows the enormous change in the streetscape that can accompany such a temporary transformation. The space, which is normally occupied to a very large extent by stationary traffic, is opened up to people in this scene.

The positive feedback from the supervisors and the results of the observations show that the playing bike primarily fulfills a transport function. In addition to the shady function of the integrated sunshade, the cargo bike itself is occasionally used for climbing attempts by younger children, its table 


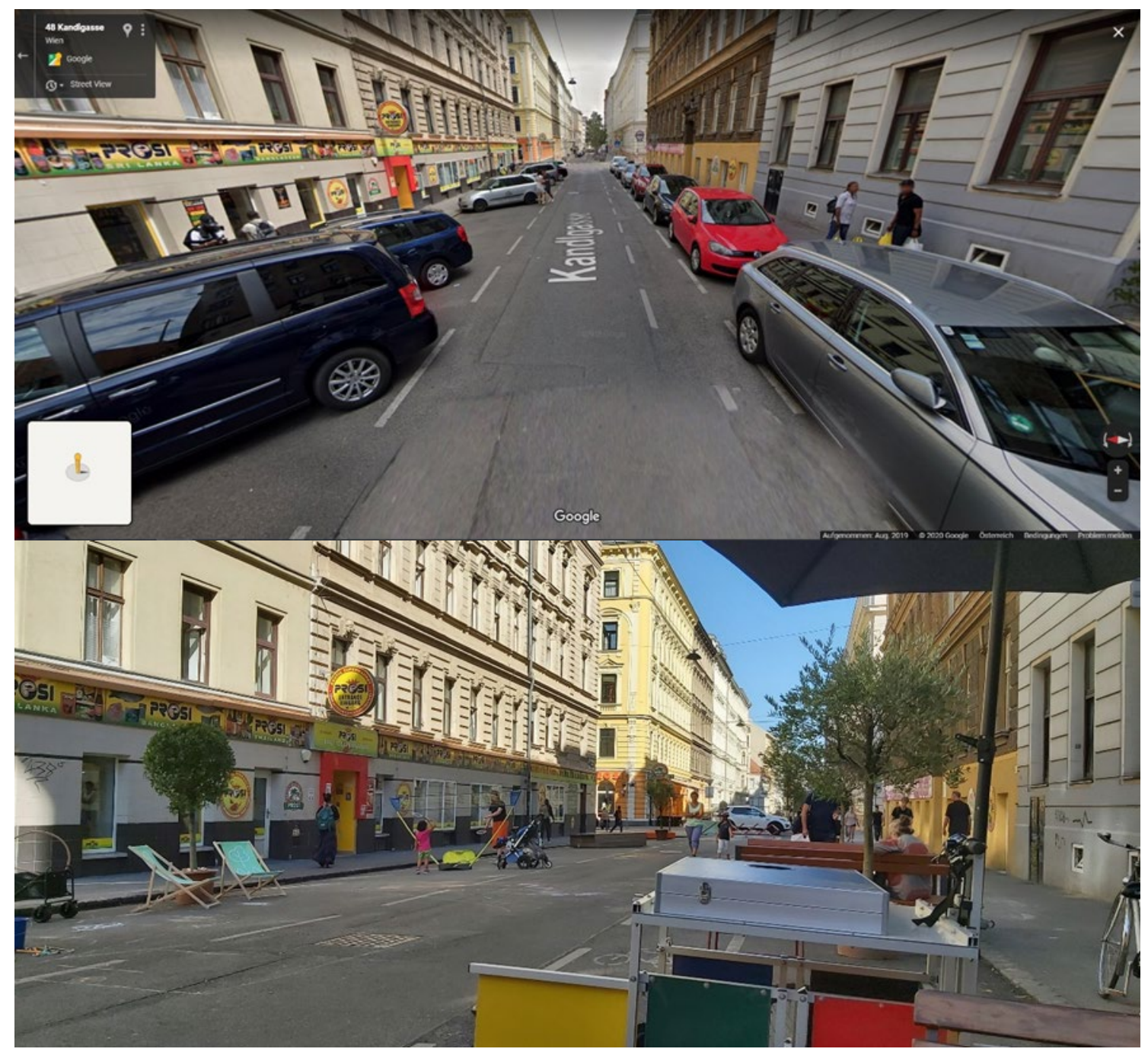

Figure 3: Street section (Kandlgasse) in Vienna before and after the intervention ("Cool Street") (Sources: Google StreetView; Sara Bafaro 2020

proved practical, e.g. for painting, but the greatest attention was focused on the toys brought along, which were very well received. The bike itself was in the background during use and thus fulfilled more of a supplementary function. In this case, it is "only" a means to an end, which is limited here, as previously mentioned, to the transport activity for toys. It transforms the space only indirectly. However, the fact that the street section is officially closed contributes to the transformation much more. In this case, the StreetFormator as a cargo bike that brings the games is a good complement to the road closure to make the most of it [20]. So when the StreetFormator is used in the context of an event, the scope of the evaluation is extended from the prototype to the environment. In this case, it also makes sense to analyze the impact evaluation of the event or action. The evaluation of the "Cool Streets" campaign shows that the general acceptance is high. This is also reflected in the approval of a repetition, although it should be noted that there are differences depending on the location. Most of the people who use the open spaces that have been created come from the immediate neighborhood. The majority visits the Cool Streets with family members, friends or relatives, but many also come alone. In addition to resting, relaxing or chilling out, a quarter of respondents use the opportunity to meet other people. In addition, nearly half of all respondents say they now spend more time outdoors. This shows that the campaign provides an opportunity for people to use public space. The survey results show that the "Cool Streets" also have a social impact. It brings people together in their district and offers them the opportunity to compensate for the lack of private or semi-public open spaces and to use the street as a meeting and communication place [21].During our surveys in Graz and Vienna (both by means of observation and interviews), we were able to conclude that the majority of the people involved (both active users and passers-by) reacted positively to the StreetFormators. Few people expressed rather negative opinions about the action. Often they felt 
disturbed by the event in general or worried about the stores, which were now less accessible by car. The same applies in general to the elimination of parking spaces. A small number of passers-by felt adversely affected by the loss of parking spaces. Those affected often expressed emotional feelings about this, which shows that the topic of removing parking spaces is a very sensitive one. Here it is particularly important to "pick up" these people, i.e. to involve them from the very beginning and to raise their awareness. A top-down approach will not be very promising in such situations. Overall, however, the benefits of the additional public space outweigh the disadvantages. In many cases, the desire for longer-term traffic calming, greening and reuse of the street space is expressed. From the evaluation and interim results to date, adjustments could be made. For example, the findings from the first test phase were incorporated into the design of the remaining StreetFormators still under construction: In the case of the "Meet \& Greet
Bike" (see figure 4), seating is attached directly to the cargo bike so that it can be used directly.

In addition, add-ons were planned that can be installed relatively flexibly, depending on the purpose/location. In addition to redesign measures, "supervised play" of the StreetFormator could also contribute to more interactions with the bike itself. This approach is difficult to implement in times of pandemic with the associated distance regulations but could be the key to success in a normal situation (when people can interact more with each other again). Also, previous deployments had shown that a certain familiarization phase was needed for the space-transformers (in particular the "playing bike" and its equipment) to be accepted and used. In retrospect, the StreetFormator's deployment period of one week per location was considered to be too short. Therefore, a period of at least 2 - preferably 3-4 weeks at the same location is planned for future pilot test actions [20]. (Fig. 4B).

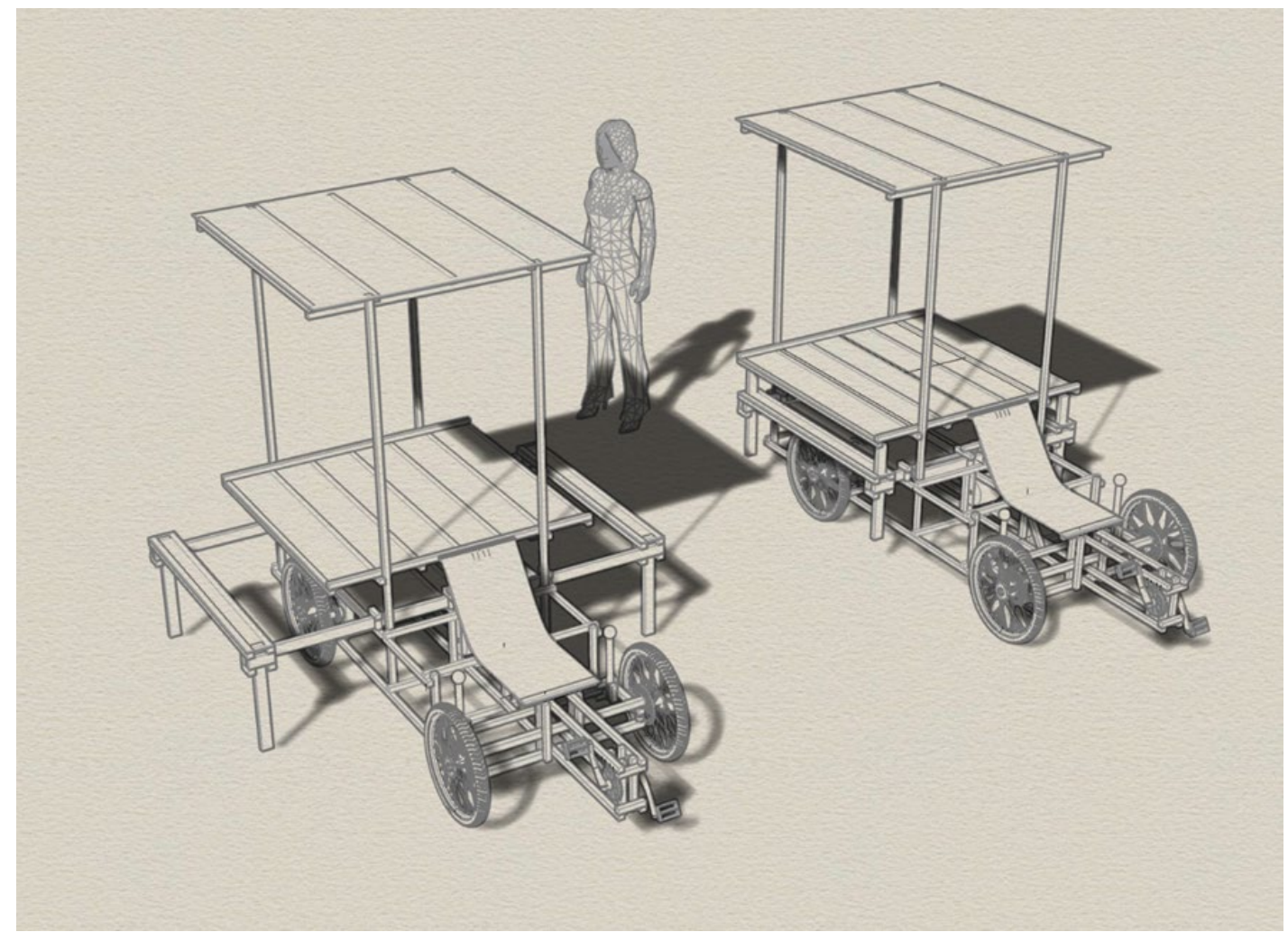

Figure 4: Planning sketch of the StreetFormator named "Meet \& Greet Bike" (Source: xyz cargo 2020

\section{CONCLUSION}

Public street space is clearly not equally accessible to all. The stationary use of cargo bikes therefore has a high potential in urban space. The cargo bikebased tool (space-transformer or StreetFormator) tested in the Pop-up Piazza project is suitable for transforming a car parking lot and transforming the space so that it can be used by more people. The pilot actions attracted attention and raised awareness on the topic. Traditional realities were broken, and thought was stimulated. The framework conditions contribute strongly to the success of the actions, for example restrictive administrative units can delay the actually fast popup transformations. Settings also determine impact. The StreetFormator tends to be in the background when used in a closed street (sparse interaction and hardly noticed) but can complement it well when it "brings" useful add-ons. If only one parking space 
is transformed by the StreetFormator, the focus is more on it and it is then also used more. For this, however, it is advisable to remove barriers as far as possible. Hosting comes into question for this. In addition to host partnerships with associations and businesses, cooperation with private individuals could be considered for the remainder of the project. Experience so far has shown that a bottom- up approach is advisable. Finally, it should be noted that the case studies of Vienna and Graz have shown that the temporary transformation of public street space creates more spaces for people to spend time in public areas, more space for social interaction, a safer area for children and a morepeople friendly environment.

\section{REFERENCES}

[1] OECD (Ed.). The Metropolitan Century: Understanding Urbanisation and its Consequences, OECD Publishing, Paris. 2015.

[2] Holden, E. \& Gilpin, G. \& Banister, D. Sustainable mobility at thirty, Sustainability, 11(7), p. 1965, 2019.

[3] Norton, P. Of love affairs and other stories. In: S. Zavestoski \& J. Agyeman (Eds.), Incomplete streets. Processes, practices, and possibilities, pp. 17-35, London \& New York, 2015.

[4] Lydon, M. \& Garcia, A. Tactical urbanism: Short-term action for long-term change. Washington, 2015.

[5] Furchtlehner, J. \& Lička, L. Back on the Street: Vianna, Copenhagen, Munich, and Rotterdam in focus, Journal of Landscape Architecture, Vol. 14, p. 72-83, 2019.

[6] ORF (Ed.). Fünf Jahre Begegnungszone Graz: Unfälle halbiert. 2016. https://steiermark.orf.at/v2/news/stories/2802854/ (accessed at 8 February 2021).

[7] Bertolini, L. From "streets for traffic" to "streets for people": can street experiments transform urban mobility?, Transport reviews, vol. 40, pp 734-753, 2020.

[8] Talen, E. Do-it-Yourself Urbanism: A History. Journal of Planning History, Vol. 14, p. 135-148, 2014.

[9] Lydon, M. Tactical Urbanism 2. Short-term Action - Long-term Change, The Street Plans Collaborative, 2012. https://issuu.com/streetplanscollaborative/docs/tactical_urbanism_vol_2_final (accessed at 8 February 2021).

[10] Silva, P. Tactical Urbanism: Towards an evolutionary cities' approach. Environment and Planning B: Planning and Design, Vol. 43, p. 1040-1051, 2016.

[11] Webb, D. Tactical Urbanism: Delineating a Critical Praxis. Planning theory \& Practice, Vol. 18, p. 58- 73, 2017.

[12] Lefebvre, H. Writings on Cities. Massachusetts, USA: Blackwell Publisher Ltd, p. 250, 1996.

[13] Harvey, D. The right to the city, International Journal of Urban and Regional Research, Vol. 27, p. 939-41, 2008.

[14] Stadt Graz (Ed.). Aufgaben des Referat für Bauplanung. 2021.

https://www.graz.at/cms/beitrag/10292555/7757978/Referat_Bebauungsplanung.html (accessed at 8 February 2021).

[15] Stadt Wien (Ed.). Auszug aus der Geschäftseinteilung des Magistrats der Stadt Wien. 2021. https://www.wien.gv.at/advuew/internet/AdvPrSrv.asp?Layout=geschaeftseinteilung\&Type=K\&Hlayout=\&STELL $\mathrm{ECD}=1995060915103983$ (accessed at 8 February 2021).

[16] Tomasulo, M. (2013): The tale of a tactic: Prologue. 2013. https://medium.com/@cityfabric/the-tale-of-a-tacticprologue-ec58d155aacb (accessed at 8 February 2021).

[17] Stadt Wien (Ed.). "Coole Straßen" sorgen für Abkühlung, 2020. https://www.wien.gv.at/verkehrstadtentwicklung/coolestrasse.html (accessed at 2 February 2021).

[18] Lokale Agenda 21 Wien (Ed.). Grätzloase. Wir verwandeln den Freiraum, 2019. https://www.graetzloase.at/ (accessed at 8 February 2021).

[19] Forschunsgesellschaft Mobilität FGM-AMOR. Projektbeschreibung für Förderungsansuchen des Programmes Mobilität der Zukunft - Pop-up Piazza. In: Kooperative F\&E-Projekte FFG. 2017.

[20] Bafaro, S. \& Senger, M. \& Giesch, M. Zwischenbericht zur Prozess- und Wirkungsevaluierung. POP-UP PIAZZA Erforschung von Transformationswerkzeugen für die temporäre Umwandlung von öffentlichem Straßenraum, 2020.

[21] Tbw research GesmbH (Ed.). Ergebnisbericht. Evaluierung der Aktion „Coole Straßen“ in Wien. Auftraggeber: Magistrat der Stadt Wien, MA 28. 2019 